\title{
AND MIDWIFERY INDONESIA
}

\section{Surveillance Kejadian Phlebitis pada Pemasangan Kateter Intravena pada Pasien Rawat Inap di Rumah Sakit Ar. Bunda Prabumulih}

\author{
Wahyu Rizky¹, Supriyatiningsih ${ }^{2}$
}

${ }^{1,2}$ Magister Manajemen Rumah Sakit, Universitas Muhammadiyah Yogyakarta

\begin{abstract}
Abstrak
Kejadian phlebitis menjadi indikator mutu pelayanan minimal rumah sakit dengan standar kejadian $\leq 1.5 \%$. Angka kejadian phlebitis di Rumah Sakit AR. Bunda Prabumulih masih tinggi berkisar antara 10\% s/d 16\%. Angka kejadian phlebitis tertinggi pada bulan April sebesar $16 \%$. Surveillance adalah suatu kegiatan yang penting untuk perencanaan, penerapan, evaluasi dan praktek-praktek pengendalian infeksi. Penelitian observasional dengan pendekatan descriptive analitik non-eksperimental menggunakan rancangan penelitian kuantitatif dengan pendekatan kohort prospektif bertujuan untuk mengetahui angka kejadian phlebitis pemasangan kateter intravena, mengetahui faktor pendukung penyebab terjadinya phlebitis pemasangan kateter intravena, dan mengetahui jenis kuman penyebab terjadinya phlebitis pada pasien rawat inap di Rumah Sakit AR. Bunda Prabumulih. Penelitian dilakukan pada bulan Juni 2013 di Rumah Sakit AR. Bunda Prabumulih. Populasi adalah seluruh pasien rawat inap yang terpasang kateter intravena. Besar sampel yang didapatkan sebanyak 17 orang yang mengalami phlebitis. Dari hasil penelitian didapatkan persentase angka kejadian phlebitis di Rumah Sakit AR. Bunda Prabmulih pada bulan Juni 2013 adalah sebesar 333.33\%. Angka kejadian phlebitis banyak terjadi di usia 31 - 50 tahun yaitu sebesar 41.2\%. Angka kejadian phlebitis banyak terjadi pada perempuan yaitu sebesar $64.7 \%$. Jenis mikroorganisme yang ditemukan pada penderita phlebitis, yaitu: staphylococcus, E coli dan staphylococcus aureus. Faktor pendukung yang dapat menimbulkan terjadinya phlebitis, yaitu: jenis cairan yang digunakan, jenis kuman terutama jenis kuman gram positif, dan prinsip sterilisasi pemasangan terapi intravena oleh petugas kesehatan. Dari hasil tersebut dapat disimpulkan bahwa angka kejadian phlebitis di Rumah Sakit AR. Bunda Prabumulih pada bulan juni 2013 sebesar 333.33 $\%$ jauh lebih besar dari standar yang ditetapkan oleh Depkes RI yaitu $\leq 1.5 \%$.
\end{abstract}

Kata Kunci: Surveillance - Pemasangan Kateter Intravena - Phlebitis

\section{Surveillance Incidence of Phlebitis on Intravenous Procedure for Hospitalized Patient at Ar. Bunda Prabumulih Hospital}

\begin{abstract}
Incidence of phlebitis is an indicator of the quality of hospital services with minimal rate of $\leq 1.5 \%$ standard. The incidence of phlebitis in Hospital AR. Bunda Prabumulih is still high ranging from $10 \%$ to $16 \%$. Highest incidence of phlebitis is in April amounted to $16 \%$. Surveillance is an important activity for the planning, implementation, evaluation and infection control practices. This was an observational study with a descriptive analytic approach, while for non-experimental research design was a prospective cohort quantitative approach. The aim was to know the incidence of intravenous catheter phlebitis, knowing the factors supporting the cause of intravenous catheter phlebitis, and to understand what kind of germs that cause the occurrence of phlebitis in patients hospitalized in AR. Bunda Prabumulih Hospital. Large samples obtained were 17 people who had phlebitis. From the results, the percentage of incidence of phlebitis in Hospital AR. Bunda Prabmulih in June 2013 amounted to $333.33 \%$. The incidence of phlebitis was happeningmostly in age of $31-50$ years at $41.2 \%$. The phlebitis occured in women at $64.7 \%$. Types of microorganisms found in phlebitis patients, namely: staphylococcus, E.coli and staphylococcus aureus. Factors which may cause the occurrence of phlebitis were the type of fluid used, types of bacteria, especially species of gram-positive bacteria, and the principle of sterilization during intravenous procedures by health workers. Additionaly, The incidence of phlebitis in Hospital AR. Bunda Prabumulih in June 2013 amounted to 333.33\% much larger than the standard set by the Depkes $R /$ is $\leq 1.5 \%$.
\end{abstract}


Info Artikel:

Artikel dikirim pada 02 Desember 2013

Artikel diterima pada 02 Desember 2013

\section{Pendahuluan}

Rumah SakitAR. Bunda Prabumulih merupakan salah satu rumah sakit swasta yang ada di Kota Prabumulih. Persaingan ketat antar rumah sakit yang ada di Kota Prabumulih saat ini, mengharuskan setiap manajemen rumah sakit untuk meningkatkan pelayanan rumah sakit khususnya keselamatan pasien rawat inap yang baik sehingga bisa memenangkan persaingan. Hal ini didukung oleh adanya Peraturan Menteri Kesehatan (PMK) Republik Indonesia No. 1691/MENKES/PER/VII/2011 tentang keselamatan pasien (Patient safety) di rumah sakit dan salah satu sasarannya, yaitu: pengurangan resiko infeksi terkait pelayanan kesehatan yang dijelaskan bab IV pasal $8 .^{1}$

Tabel 1. Angka kejadian phlebitis di Rumah Sakit AR. Bunda Prabumulih tahun 2010

\begin{tabular}{lccc}
\hline Bulan & $\begin{array}{c}\text { Jumlah pasien } \\
\text { yang di pasang } \\
\text { infus }\end{array}$ & $\begin{array}{c}\text { Jumlah } \\
\text { pasien } \\
\text { phlebitis }\end{array}$ & $\begin{array}{c}\% \\
\text { phlebitis }\end{array}$ \\
\hline Januari & 122 & 12 & $10 \%$ \\
Februari & 175 & 22 & $13 \%$ \\
Maret & 199 & 23 & $12 \%$ \\
April & 188 & 30 & $16 \%$ \\
Mei & 219 & 23 & $11 \%$ \\
Juni & 195 & 26 & $13 \%$ \\
Juli & 163 & 23 & $14 \%$ \\
Agustus & 167 & 25 & $15 \%$ \\
September & 236 & 23 & $10 \%$ \\
Oktober & 130 & 16 & $12 \%$ \\
November & 184 & 18 & $10 \%$ \\
Desember & 160 & 18 & $11 \%$ \\
\hline
\end{tabular}

Sumber: Data Primer

Angka kejadian phlebitis turun naik tetapi pada bulan April 2010 jumlah pasien yang phlebitis sebesar $16 \%$, angka ini lebih besar dari bulan yang lainnya. Penilaian phlebitis dilakukan dengan melihat tandatanda kejadian phlebitis pada pasien seperti terasa nyeri, panas, kemerah-merahan dan terdapatnya edema (bengkak) pada permukaan kulit, dengan metode perawatan infus yang sama. pada tahun 2011 dan 2012 sudah dilakukan surveillance tetapi data yang didapat masih berupa data mentah dan belum dihitung secara komputerisasi.

Berdasarkan latar belakang diatas peneliti menganggap perlu dilakukan penelitian ini tentang surveillance kejadian phlebitis pada pemasangan kateter intravena pada pasien rawat inap di Rumah Sakit AR. Bunda Prabumulih.

Berdasarkan kerangka berpikir tersebut dan dengan memperlihatkan fakta-fakta yang ada dapat dirumuskan pertanyaan permasalahan, yaitu:

a. Berapakah angka kejadian phlebitis pada pemasangan kateter intravena pada pasien rawat inap di Rumah Sakit AR. Bunda Prabumulih?

b. Apakah faktor pendukung penyebab terjadinya phlebitis pada pemasangan kateter intravena pada pasien rawat inap di Rumah SakitAR. Bunda Prabumulih?

c. Apakah jenis kuman penyebab terjadinya phlebitis pada pasien rawat inap di Rumah SakitAR. Bunda Prabumulih?

\section{Bahan dan Metode \\ Jenis Penelitian}

Jenis penelitian ini merupakan penelitian observasional dengan pendekatan descriptive analitik non-eksperimental sedangkan untuk rancangan penelitiannya adalah kuantitatif dengan pendekatan kohort prospektif . ${ }^{2}$

\section{Subyek Penelitian}

Subyek penelitian ini adalah pasien rawat inap yang menggunakan kateter intravena di ruang perawatan Ibnu Sina (bedah), Musdalifah (penyakit dalam), Al-Warda (ruang perawatan klas III dewasa), dan Al-Wildan (ruang perawatan anak) Rumah Sakit AR. Bunda Prabumulih.

Kriteria Inklusi:

a. Jenis kelamin laki-laki dan perempuan

b. Pasien rawat inap yang menggunakan kateter intravena di ruang perawatan Ibnu Sina (bedah), Musdalifah (penyakit dalam), Al-Warda (ruang perawatan klas III dewasa), dan Al-Wildan (ruang perawatan anak) Rumah Sakit AR. Bunda Prabumulih.

c. Pasien bersedia menjadi responden.

Sedangakan kriteria eksklusi pada penelitian ini adalah pasien rawat inap yang tidak menggunakan kateter intravena di ruang perawatan Ibnu Sina (bedah), Musdalifah (penyakit dalam), Al-Warda 
(ruang perawatan klas III dewasa), dan Al-Wildan (ruang perawatan anak) Rumah Sakit AR. Bunda Prabumulih.

\section{Populasi, Sampel, dan Sampling}

Populasi dalam penelitian ini adalah pasien rawat inap yang menggunakan kateter intravena di Rumah Sakit AR. Bunda Prabumulih. Sampel penelitian ini menggunakan accidental sampling yaitu pengambilan sampel di lakukan dengan kasus atau responden yang kebetulan ada atau tersedia di suatu tempat sesuai dengan konteks penelitian. ${ }^{3}$

\section{Definisi Operasional}

Kateter intravena adalah salah satu cara atau bagian dari pengobatan untuk memasukkan obat atau vitamin ke dalam tubuh pasien. Phlebitis adalah inflamasi vena yang disebabkan oleh iritasi kimia maupun mekanik.

Pengukuran untuk variabel phlebitis menggunakan lembar observasi untuk screening sedangkan untuk menilai skor visual untuk phlebitis menggunakan VIP score (Visual Infusion Phlebitis Score) yang telah dikembangkan oleh Andrew Jackson.

\section{Instrumen Penelitian}

Penelitian ini menggunakan alat ukur berupa lembar observasi untuk screening sampel pada hari pemasangan infus dengan memberi jawaban pada kolom pengamatan sesuai hasil pengamatan dan lembar observasi penilaian untuk melihat kejadian phlebitis mulai hari pertama pemasangan infus sampai dengan infus dilepas atau pasien pindah ruangan atau pulang atau pasian meninggal, dengan memberi tanda pada kolom "ya" atau "tidak" sesuai kriteria yang telah ditentukan dan memberi jawaban pada kolom pengamatan sesuai hasil pengamatan dan catatan keperawatan pada hari tersebut. Untuk menilai skor visual untuk phlebitis peneliti menggunakan VIP score (Visual Infusion Phlebitis Score) yang telah dikembangkan oleh Andrew Jackson.

Tabel 1. Visual Infusion Phlebitis Score

\begin{tabular}{|c|c|c|}
\hline SKOR & $\begin{array}{l}\text { KEADAAN AREA } \\
\text { PENUSUKAN }\end{array}$ & PENILAIAN \\
\hline 0 & $\begin{array}{l}\text { Tempat suntikan tampak } \\
\text { sehat }\end{array}$ & $\begin{array}{l}\text { Tidak ada tanda } \\
\text { phlebitis }\end{array}$ \\
\hline 1 & $\begin{array}{l}\text { Salah satu dari berikut jelas: } \\
\text { a. Nyeri area penusukan } \\
\text { b. Adanya eritema di area } \\
\text { penusukan }\end{array}$ & $\begin{array}{l}\text { Mungkin tanda } \\
\text { dini phlebitis }\end{array}$ \\
\hline
\end{tabular}

\begin{tabular}{|c|c|c|}
\hline 2 & $\begin{array}{l}\text { Dua dari berikut jelas: } \\
\text { a. Nyeri penusukan } \\
\text { b. Eritema } \\
\text { c. Pembengkakan }\end{array}$ & $\begin{array}{l}\text { Stadium dini } \\
\text { phlebitis }\end{array}$ \\
\hline 3 & $\begin{array}{l}\text { Semua dari berikut jelas: } \\
\text { a. Nyeri sepanjang kanul } \\
\text { b. Eritema } \\
\text { c. Indurasi }\end{array}$ & $\begin{array}{l}\text { Stadium moderat } \\
\text { phlebitis }\end{array}$ \\
\hline 4 & $\begin{array}{l}\text { Semua dari berikut jelas: } \\
\text { a. Nyeri sepanjang kanul } \\
\text { b. Eritema } \\
\text { c. Indurasi } \\
\text { d. Venous chord teraba }\end{array}$ & $\begin{array}{l}\text { Stadium lanjut } \\
\text { a t a u a wa I } \\
\text { thrombophlebitis }\end{array}$ \\
\hline 5 & $\begin{array}{l}\text { Semua dari berikut jelas: } \\
\text { a. Nyeri sepanjang kanul } \\
\text { b. Eritema } \\
\text { c. Venous chourd teraba } \\
\text { d. Demam }\end{array}$ & $\begin{array}{l}\text { Stadium Lanjut } \\
\text { thrombophlebitis }\end{array}$ \\
\hline
\end{tabular}

\section{Hasil dan Pembahasan \\ Karakteristik Subyek Penelitian}

Subyek dalam penelitian ini adalah pasien rawat inap yang terpasang kateter intravena yang mengalami phlebitis di Rumah Sakit AR. Bunda Prabumulih dengan jumlah 17 dari 191 total subjek penelitian.

Berdasarkan tabel 2 terlihat bahwa sebagian besar responden berada dalam kelompok usia 31 - 50 tahun yaitu sebesar $41.2 \%$ dan jumlah responden paling sedikit pada kelompok usia $\leq 10$ tahun yaitu sebesar $11.8 \%$. Dalam penelitian ini terlihat bahwa sebagian besar responden berjenis kelamin perempuan yaitu sebesar $64.7 \%$, sedangkan untuk responden berjenis kelamin laki-laki sebesar $35.3 \%$. Jenis cairan Otsu RL yang dapat paling banyak menimbulkan phlebitis yaitu sebesar $29.4 \%$, sedangkan untuk jenis cairan yang paling sedikit menimbulkan phlebitis yaitu jenis cairan Asering dan KA-EN 3A masing-masing sebesar 5.9\%. Ukuran kanula $22 \mathrm{G}$ paling banyak menimbulkan phlebitis yaitu sebesar $76.4 \%$, sedangkan untuk ukuran kanula yang paling sedikit menimbulkan phlebitis yaitu ukuran kanula 18G dan 20G masing-masing sebesar 5.9\%. Sebagian besar tempat penusukannya di vena yaitu sebesar $100.0 \%$. Sebagian besar gejala klinis phlebitis ditandai dengan nyeri atau panas $\geq 38^{\circ} \mathrm{C}$ ditempat penusukan yaitu sebesar $64.7 \%$, sedangkan gejala klinis yang paling sedikit atau tidak ada yaitu garis kemerahan di saluran vena sebesar $0.0 \%$. Sebagian besar diagnosa medis dispepsia yang menimbulakan phlebitis ditempat penusukan yaitu sebesar $17.6 \%$, sedangkan diagnosa medis yang paling sedikit yaitu cephalgia, diabetes mellitus, diarrhea, kelenjar tiroid, post partum, dan PEB (Pre Eklamsia Berat) masing-masing sebesar 5.9\% 
Tabel 2. Karakteristik pasien berdasarkan kelompok usia yang mengalami phlebitis pada bulan Juni 2013

\begin{tabular}{|c|c|c|c|c|c|}
\hline \multicolumn{6}{|c|}{ Usia } \\
\hline & & Frequency & Percent & Valid Percent & Cumulative Percent \\
\hline \multirow[t]{5}{*}{ Valid } & $\leq 10$ tahun & 2 & 11.8 & 11.8 & 11.8 \\
\hline & $11-30$ tahun & 5 & 29.4 & 29.4 & 41.2 \\
\hline & 31 - 50 tahun & 7 & 41.2 & 41.2 & 82.4 \\
\hline & 51 - 70 tahun & 3 & 17.6 & 17.6 & 100.0 \\
\hline & Total & 17 & 100.0 & 100.0 & \\
\hline \multicolumn{6}{|c|}{ Jenis kelamin } \\
\hline & & Frequency & Percent & Valid Percent & Cumulative Percent \\
\hline \multirow[t]{3}{*}{ Valid } & Laki-laki & 6 & 35.3 & 35.3 & 35.3 \\
\hline & Perempuan & 11 & 64.7 & 64.7 & 100.0 \\
\hline & Total & 17 & 100.0 & 100.0 & \\
\hline \multicolumn{6}{|c|}{ Jenis cairan } \\
\hline & & Frequency & Percent & Valid Percent & Cumulative Percent \\
\hline \multirow[t]{8}{*}{ Valid } & Otsu RL & 5 & 29.4 & 29.4 & 29.4 \\
\hline & $\mathrm{RL}$ & 3 & 17.6 & 17.6 & 47.0 \\
\hline & Otsu D5 & 3 & 17.6 & 17.6 & 64.6 \\
\hline & Wida RL & 2 & 11.8 & 11.8 & 76.4 \\
\hline & Asering & 1 & 5.9 & 5.9 & 82.3 \\
\hline & KA-EN 3A & 1 & 5.9 & 5.9 & 88.2 \\
\hline & KA-EN 3B & 2 & 11.8 & 11.8 & 100 \\
\hline & Total & 17 & 100.0 & 100.0 & \\
\hline \multicolumn{6}{|c|}{ Ukuran kanula } \\
\hline & & Frequency & Percent & Valid Percent & Cumulative Percent \\
\hline \multirow[t]{5}{*}{ Valid } & $18 \mathrm{G}$ & 1 & 5.9 & 5.9 & 5.9 \\
\hline & $20 \mathrm{G}$ & 1 & 5.9 & 5.9 & 11.8 \\
\hline & $22 \mathrm{G}$ & 13 & 76.4 & 76.4 & 88.2 \\
\hline & $24 \mathrm{G}$ & 2 & 11.8 & 11.8 & 100.0 \\
\hline & Total & 17 & 100.0 & 100.0 & \\
\hline \multicolumn{6}{|c|}{ Tempat penusukan } \\
\hline & & Frequency & Percent & Valid Percent & Cumulative Percent \\
\hline \multirow[t]{3}{*}{ Valid } & Vena & 17 & 100.0 & 100.0 & 100.0 \\
\hline & DII & 0 & 0.0 & 0.0 & \\
\hline & Total & 17 & 100.0 & 100.0 & \\
\hline \multicolumn{6}{|c|}{ Gejala klinis phlebitis } \\
\hline & & & Frequency & Percent & Cumulative Percent \\
\hline \multirow[t]{5}{*}{ Valid } & Nyeri atau pane & & 11 & 64.7 & 64.7 \\
\hline & Kemerahan & & 4 & 23.5 & 88.2 \\
\hline & Edema (bengka & & 2 & 11.8 & 100.0 \\
\hline & Garis kemerahe & & 0 & 0.0 & \\
\hline & Total & & 17 & 100.0 & \\
\hline \multicolumn{6}{|c|}{ Diagnosa medis } \\
\hline & & & Frequency & Percent & Cumulative Percent \\
\hline \multirow[t]{12}{*}{ Valid } & Cephalgia & & 1 & 5.9 & 5.9 \\
\hline & Diabetes mellitı & & 1 & 5.9 & 11.8 \\
\hline & Diarrhea & & 1 & 5.9 & 17.7 \\
\hline & Dispepsia & & 3 & 17.6 & 35.3 \\
\hline & Dispnue & & 2 & 11.8 & 47.1 \\
\hline & GEA (Gastroen & ut) & 2 & 11.8 & 58.9 \\
\hline & Hipertensi & & 2 & 11.8 & 70.7 \\
\hline & Kelenjar tiroid & & 1 & 5.9 & 76.6 \\
\hline & Post partum & & 1 & 5.9 & 82.5 \\
\hline & PEB (Pre Eklan & & 1 & 5.9 & 88.4 \\
\hline & Tiphus/tipes & & 2 & 11.8 & 100.0 \\
\hline & Total & & 17 & 100.0 & \\
\hline
\end{tabular}

Sumber: Data primer 
Surveillance angka kejadian phlebitis di Rumah Sakit AR. Bunda Prabumulih dilakukan di empat ruang perawatan, yaitu: ruang perawatan Ibnu Sina (bedah), Musdalifah (penyakit dalam), Al-Warda (ruang perawatan klas III dewasa), dan Al-Wildan (ruang perawatan anak).

Analisis data penelitian ini menggunakan rumus proporsi sebagai berikut:

Iumlah pasien yang terpasang infus lama hari terjadi $\quad X 1000$

Berikut adalah analisis data kejadian phlebitis di masing-masing ruang perawatan Rumah Sakit AR. Bunda Prabumulih.

Tabel 3. Angka kejadian phlebitis di masing-masing ruang perawatan Rumah Sakit AR. Bunda Prabumulih pada bulan Juni 2013

\begin{tabular}{lccc}
\hline \multirow{2}{*}{\multicolumn{1}{c}{ Ruang perawatan }} & \multicolumn{3}{c}{$\begin{array}{c}\text { Angka kejadian } \\
\text { phlebitis }\end{array}$} \\
\cline { 2 - 4 } & $\mathrm{n}$ & $\mathrm{f}$ & $\%$ \\
\hline Ibnu Sina (bedah) & 88 & 7 & 333.33 \\
$\begin{array}{l}\text { Musdalifah (penyakit dalam) } \\
\text { Al-Warda (ruang perawatan } \\
\text { klas III dewasa) }\end{array}$ & 52 & 5 & 333.33 \\
$\begin{array}{l}\text { Al-Wildan (ruang perawatan } \\
\text { anak) }\end{array}$ & 26 & 3 & 333.33 \\
\hline
\end{tabular}

Sumber: Data primer

Tabel 3. menunjukkan angka kejadian phlebitis yang paling banyak di ruang perawatan ibnu sina (bedah) yaitu sebanyak 7 pasien. Sedangkan angka kejadian phlebitis yang paling sedikit diruang perawatan al-wildan (ruang perawatan anak) sebanyak 2 pasien.

Tabel 4. Angka kejadian phlebitis di Rumah Sakit AR. Bunda Prabumulih pada bulan Juni 2013

\begin{tabular}{lccc}
\hline & \multicolumn{3}{c}{ Angka kejadian phlebitis } \\
\cline { 2 - 4 } & $\mathrm{n}$ & $\mathrm{f}$ & $\%$ \\
\hline $\begin{array}{l}\text { Rumah Sakit AR. } \\
\text { Bunda Prabumulih }\end{array}$ & 191 & 17 & 333.33 \\
\hline
\end{tabular}

Sumber: Data primer

Tabel 4. menunjukkan angka kejadian phlebitis di Rumah Sakit AR. Bunda pada bulan Juni 2013 yaitu $333.33 \%$.

Setelah dilakukan observasi selama 30 hari dari 17 pasien yang terkena phlebitis, ada lima pasien yang di lakukan kultur pada bagian yang terlihat tanda dan gejala phlebitis. Hasil dari kultur kuman yang sering dijumpai pada pemasangan kateter intravena adalah staphylococcus, E coli, dan staphylococcus aureus.

\section{Pembahasan}

Phlebitis merupakan inflamasi vena yang disebabkan oleh iritasi kimia maupun mekanik. Hal ini ditunjukkan dengan adanya daerah yang merah, nyeri dan pembengkakan di daerah penusukan atau sepanjang vena. Insiden phlebitis meningkat sesuai dengan lamanya pemasangan jalur intravena. Komplikasi cairan atau obat yang diinfuskan (terutama $\mathrm{pH}$ dan tonisitasnya), ukuran dan tempat kanula yang dimasukkan, pemasangan jalur intravena yang tidak sesuai, dan masuknya mikroorganisme pada saat penusukan. ${ }^{4}$

Daya tahan tubuh pada usia lanjut menjadi kurang efektif. Usia yang sudah lanjut perubahanperubahan dalam sistem kekebalan tubuh terjadi terutama pada sel T-limfosit sebagai hasil dari penuaan. Pertahanan terhadap infeksi dapat berubah sesuai dengan bertambahnya umur. Pada usia lanjut (>60 tahun) vena akan menjadi rapuh, tidak elastis, dan mudah hilang atau kolaps, pasien anak vena yang kecil dan keadaan yang banyak bergerak dapat mengakibatkan kateter intravena bergeser sehingga akan menyebabkan phlebitis. ${ }^{5}$

Penelitian yang dilakukan oleh Darmanto (2008, $\mathrm{hlm}$. 38) yang berjudul hubungan pemasangan infus dengan kejadian phlebitis pada pasien berbagai tingkat usia diruang Cempaka RSUD Sunan Kalijaga Demak diperoleh dari 33 responden, usia $31-40$ tahun yang mengalami phlebitis sebesar $12.1 \%$ dan sangat berbeda dengan penelitian yang dilakukan oleh Suryati (2010) hasil penelitiannya menyebutkan bahwa umur responden yang lebih banyak terkena phlebitis adalah usia antara 41 - 60 tahun.

Hasil penelitian ini menunjukkan tidak adanya hubungan bermakna antara usia responden dengan kejadian phlebitis karena phlebitis dapat terjadi pada siapa saja tanpa batas usia, walaupun kejadian phlebitis sering terjadi pada pasien yang berusia diatas 40 tahun. ${ }^{6}$

Berdasarkan hasil karakteristik pasien berdasarkan jenis kelamin, kejadian phlebitis lebih banyak berjenis kelamin perempuan yaitu sebesar $64.7 \%$, sedangkan untuk responden berjenis kelamin laki-laki sebesar $35.3 \%$. hal ini sesuai dengan penelitian yang dilakukan oleh Campbell (1998) yang diperoleh hasil bahwa pasien yang mengalami phlebitis lebih banyak terjadi pada perempuan yaitu sebesar $58 \%$ dibandingkan dengan berjenis kelamin laki-laki. Hal ini dikemukakan juga oleh Tully, et al. (1981); Tiger, et al. (1993); Maki and Ringer (1991); Dibbel, et al. (1991) dalam Campbell (1998) menemukan bahwa jenis kelamin mempunyai pengaruh terhadap kejadian phlebitis, jenis kelamin 
perempuan meningkatkan resiko terjadinya phlebitis. Hal ini mungkin terjadi karena pada pasien perempuan akan cenderung mobilisasi tinggi dibandingkan dengan laki-laki. Hal inilah yang meningkatkan resiko phlebitis lebih tinggi pada perempuan dibandingkan dengan laki-laki.

Berbeda dengan penelitian yang dilakukan oleh Kusuma (2010) menyebutkan bahwa responden yang berjenis kelamin laki-laki lebih besar mengalami phlebitis dibandingkan dengan yang berjenis kelamin perempuan yaitu sebesar $40.50 \%$ dan perempuan hanya sebesar $35.20 \%$. Hasil ini menyebutkan bahwa tidak ada hubungan yang bermakna antara jenis kelamin dengan kejadian phlebitis.

Perempuan yang menggunakan kontrasepsi kombinasi (mengandung estrogen dan progesteron, oral, dan suntikan) mudah untuk mengalami. ${ }^{4}$ Selain itu struktur kulit laki-laki dan perempuan pada umumnya sama, dari anatomi kulit manusia yang terdiri dari epidermis, dermis, dan hipodermis dan organ didalamnya juga sama yang membedakannya hanya hormonal. Pada laki-laki terdapat hormon androgen yang berfungsi untuk merangsang kelenjar minyak lebih aktif sedangkan pada wanita tidak mempunyai hormon androgen. ${ }^{7}$

Reaksi peradangan dapat terjadi akibat dari jenis cairan yang diberikan. $\mathrm{pH}$ darah normal terletak antara 7.35 - 7.45 dan cenderung basa. pH cairan yang diperlukan dalam pemberian terapi adalah 7.00 yang berarti netral sesuai dengan $\mathrm{pH}$ darah normal. Ada kalanya suatu larutan diperlukan konsentrasi yang lebih asam untuk mencegah terjadinya karamelisasi dekstosa dalam sterilisai autoclaf, jadi larutan yang mengandung glukosa, asam amino, dan lipid bersifat flebitogenik.

Osmolalitas dapat diartikan sebagai konsentrasi sebuah larutan atau jumlah partikel yang larut dalam suatu larutan. Pada orang sehat konsentrasi plasma manusia adalah $285 \pm 10 \mathrm{mOsm} / \mathrm{kg} \mathrm{H} \mathrm{H}_{2} \mathrm{O}$. Larutan sering dikategorikan sebagai larutan isotonik, hipotonik atau hipertonik, sesuai dengan osmolalitas total larutan tersebut dibanding dengan osmolalitas plasma. Larutan isotonik adalah larutan yang memiliki osmolalitas total sebesar 280 - 310 mOsm/L, larutan yang memliki osmolalitas kurang dari itu disebut hipotonik, sedangkan yang melebihi disebut larutan hipertonik. Tonisitas suatu larutan tidak hanya berpengaruh terhadap status fisik klien akan tetapi juga berpengaruh terhadap tunika intima pembuluh darah. Dinding tunika intima akan mengalami trauma pada pemberian larutan hiperosmoler yang mempunyai osmolalitas lebih dari $600 \mathrm{mOsm} / \mathrm{L}$. Terlebih lagi pada saat pemberian dengan tetesan cepat pada pembuluh vena yang kecil. Cairan isotonik akan menjadi lebih hiperosmoler apabila ditambah dengan obat, elektrolit maupun nutrisi. ${ }^{5}$

Distribusi responden berdasarkan ukuran kanula yang menimbulkan phlebitis. Penelitian ini terlihat bahwa ukuran kanula $22 \mathrm{G}$ paling banyak menimbulkan phlebitis yaitu sebesar $76.4 \%$, sedangkan untuk ukuran kanula yang paling sedikit menimbulkan phlebitis yaitu ukuran kanula $18 \mathrm{G}$ dan $20 \mathrm{G}$ masingmasing sebesar 5.9\%. Ukuran kanula nomor $16 \mathrm{G}$ biasanya digunakan untuk bedah mayor atau trauma, ukuran kanula nomor $18 \mathrm{G}$ digunakan untuk transfusi darah. Ukuran kanula nomor 20G - 22G digunakan untuk cairan intravena dan kebanyakan pasien, tetapi ukuran kanula nomor 22G digunakan untuk anakanak dan orang dewasa sedangkan untuk ukuran kanula nomor $24 \mathrm{G}$ digunakan pada pasien pediatrik dan neonatus. ${ }^{8}$

Ukuran kateter dengan ukuran jarum yang cukup besar dapat menimbulkan phlebitis dikarenakan adanya persinggungan pembuluh darah secara berlebihan. $^{9}$

Banyak tempat yang dapat digunakan untuk terapi intravena. Vena di daerah ekstermitas dipilih sebagai lokasi perifer dan pada mulanya merupakan tempat satu-satunya yang digunakan perawat. Terdapat beberapa jalur penusukan yang biasa dilakukan oleh perawat, yaitu: lengan, punggung tangan dan punggung kaki. Penggunaan vena didaerah kaki biasanya digunakan pada pasien anak-anak tetapi pada orang dewasa juga dapat digunakan pada kasus-kasus tertentu seperti resiko tromboemboli. Vena-vena yang biasa dihindari adalah vena dibawah infiltrasi vena sebelumnya atau dibawah area yang terkena phlebitis, vena yang sklerotik atau bertrombus, lengan dengan pirai arteriovena atau vistula, lengan yang mengalami edema, infeksi, bekuan darah, atau kerusakan kulit, lengan yang mengalami mastektomi. Idealnya, kedua lengan dan tangan harus di inspeksi dengan cermat sebelum melakukan fungsi vena. Lokasi dipilih, lokasi yang tidak mengganggu mobilisai fisik. Lokasi yang dipilih adalah yang paling distal dari lengan dan tangan. ${ }^{10}$

Distribusi responden berdasarkan gejala klinis yang menimbulkan phlebitis. Penelitian ini terlihat bahwa sebagian besar gejala klinis phlebitis di tandai dengan nyeri atau panas $\geq 38^{\circ} \mathrm{C}$ ditempat penusukan yaitu sebesar $64.7 \%$, sedangkan gejala klinis yang paling sedikit atau tidak ada yaitu garis kemerahan di saluran vena sebesar $0.0 \%$. Hal tersebut menunjukkan mungkin tanda dini terjadinya phlebitis dengan skor visual 1. Hal ini sangat berbeda dengan penelitian yang dilakukan oleh Nurjanah (2011) yang berjudul hubungan antara lokasi penusukan infus dan tingkat usia dengan kejadian phlebitis diruang rawat inap 
dewasa RSUD Tugurejo Semarang yang hasil penelitiannya bahwa untuk skala phlebitis yang paling sering muncul adalah skala 2 sebanyak $21.4 \%$, yaitu dengan tanda dan gejala adanya nyeri penusukan, eritema, dan pembengkakan.

Dalam hal ini sesuai dengan teori yang disampaikan oleh Aryani, et al., (2009, hal. 129) kejadian phlebitis dengan skala 2 memiliki tanda gejala nyeri penusukan, eritema, dan pembengkakan. Hasil penelitian ini sangat berbeda dengan penelitian yang dilakukan oleh Nurjanah. Penilaian skala skor phlebitis dipengaruhi oleh tanggung jawab perawat dalam melakukan pendeteksian secara dini perkembangan phlebitis di setiap rumah sakit.

Distribusi responden berdasarkan diagnosa medis yang menimbulkan phlebitis. Penelitian ini terlihat bahwa sebagian besar diagnosa medis dispepsia yang menimbulakan phlebitis ditempat penusukan yaitu sebesar $17.6 \%$, sedangkan diagnosa medis yang paling sedikit yaitu cephalgia, diabetes mellitus, diarrhea, kelenjar tiroid, post partum, dan PEB (Pre Eklamsia Berat) masing-masing sebesar $5.9 \%$. Penyakit yang diderita pasien dapat mempengaruhi terjadinya phlebitis, misalnya pada pasien Diabetes Millitus (DM) yang mengalami aterosklerosis akan mengakibatkan aliran darah ke perifer berkurang sehingga jika terdapat luka mudah mengalami infeksi. ${ }^{11}$

Angka kejadian phlebitis yang paling banyak diruang perawatan ibnu sina (bedah) yaitu sebanyak 7 pasien. Sedangkan angka kejadian phlebitis yang paling sedikit diruang perawatan al-wildan (ruang perawatan anak) sebanyak 2 pasien. Hal menunjukkan bahwa pasien dengan kasus bedah biasanya membutuhkan jenis obat yang banyak dan jenis cairan yang beraneka ragam yang kemungkinan sebagai faktor pendukung terjadinya phlebitis.

Hasil penelitian menunjukkan bahwa angka kejadian phlebitis di Rumah Sakit AR. Bunda Prabumulih pada bulan Juni 2013 menunjukkan angka kejadian phlebitis yaitu $333.33 \%$. Angka tersebut jauh lebih besar dari standar yang ditetapkan oleh Depkes RI yaitu $\leq 1.5 \%$. Sementara angka kejadian phlebitis pada tahun 2010 rata-rata sebesar $13 \%$. Perbedaan angka dalam penelitian dengan angka resmi yang dilaporkan rumah sakit dapat disebabkan karena adanya perbedaan rumus yang digunakan dalam penilaian terhadap kejadian phlebitis. Rumus penelitian yang digunakan dalam penelitian ini adalah:

Iumlah pasien yang terpasang infus lama hari terjadi $\quad X 1000$
Sementara rumus yang digunakan oleh rumah sakit adalah

jumlah pasien phlebitis

jumlah pasien yang dipasang infus $\times 100 \%$

Hasil penelitian ini berbeda dengan pernyataan yang dikemukakan oleh Pujasari dan Sumarwati (2002) yang menyatakan bahwa angka kejadian phlebitis di Indonesia umumnya berkisar $10 \%$. Pendapat yang berbeda juga yang dikemukakan oleh Champbell (1998) yang mengatakan angka kejadian phlebitis berkisar antara $20-80 \%$. Sementara hasil yang dilakukan oleh Gayatri dan Handiyani (2008) mendapatkan kejadian phlebitis sebesar $35.8 \%$.

Berdasarkan hasil kultur kuman dari 17 pasien yang terkena phlebitis, jenis kuman yang sering dijumpai pada pemasangan kateter intravena adalah staphylococcus, E coli dan staphylococcus aureus.

Kebanyakan infeksi terkait dengan nonepidemic perfusi disebabkan selama atau setelah insersi dikarenakan adanya kontamiasi kateter oleh organisme dari kulit pasien sendiri. Bakteri gram positif seperti staphylococus aureus yang koagulase staphylococus termasuk staphylococus epidermis para enterecocus dan spesies candida bertanggung jawab besar dalam meningkatkan proporsi infeksi yang berhubungan dengan infus. ${ }^{4}$

Berdasarkan laporan dari The Centers for Disease Control and Prevention (CDC) tahun 2002 dalam artikel intravaskuler catheter-related infection in adult and pediatric kuman yang sering dijumpai pada pemasangan kateter infus adalah staphylococus dan bakteri gram negatif, tetapi dengan epidemic HIV / AIDS infeksi oleh karena jamur dilaporkan meningkat.

Adanya bakterial phlebitis bisa menjadi masalah yang serius sebagai predisposisi komplikasi sistemik yaitu septicemia. Faktor-faktor yang berperan dalam kejadian phlebitis bakteri, antara lain:

1. Tehnik cuci tangan yang tidak baik.

2. Tehnik aseptik yang kurang pada saat penusukan.

3. Tehnik pemasangan kateter yang buruk.

4. Pemasangan yang terlalu lama.

Prinsip pemasangan terapi intravena (infus) memperhatikan prinsip sterilisasi, hal ini dilakukan untuk mencegah kontaminasi jarum intravena (infus).

\section{Simpulan}

Berdasarkan hasil penelitian maka dapat disimpulkan bahwa angka kejadian phlebitis di Rumah 
Sakit AR. Bunda Prabumulih pada bulan juni 2013 sebesar $333.33 \%$ jauh lebih besar dari standar yang ditetapkan oleh Depkes RI yaitu $\leq 1.5 \%$, angka kejadian phlebitis banyak terjadi di usia 31 - 50 tahun yaitu sebesar $41.2 \%$ dikarenakan usia yang sudah lanjut adanya perubahan-perubahan dalam sistem kekebalan tubuh, terutama pada sel T-limfosit sebagai hasil dari penuaan, dan angka kejadian phlebitis banyak terjadi pada perempuan yaitu sebesar $64.7 \%$. Hal ini mungkin terjadi karena pada pasien perempuan akan cenderung mobilisasi tinggi dibandingkan dengan laki-laki. Hal inilah yang meningkatkan resiko phlebitis lebih tinggi pada perempuan dibanding lakilaki. Selain itu disebabkan karena perempuan yang menggunakan kontrasepsi kombinasi (mengandung estrogen dan progesteron, oral, dan suntikan) mudah untuk mengalami phlebitis.

\section{Daftar Pustaka}

1. Peraturan Menteri Kesehatan (PMK) Republik Indonesia No. 1691/MENKES/PER/VII/2011 tentang keselamatan pasien (Patient safety) di rumah sakit

2. Sastroasmoro, S., \& Ismael, S. (2010). Dasardasar Metodologi Penelitian Klinis. Edisi ke-3. Jakarta: CV Sagung seto.
3. Smeltzer \& Bare, (2002). Buku Ajar Keperawatan Medikal Bedah Brunner \&Suddarth. Edisi 8.Jakarta: EGC.

4. Brunnert \& Suddart, (2002). Keperawatan Medikal Bedah. Edisi.8. Vol.1. Jakarta, EGC.

5. Hankins, Lansway, dkk, (2001). Infusion Terapi In Clinical Practice. Philadelphia, W.B Saunders Company.

6. Bakta, M (2007). Trombosis dan Usia Lanjut, Divisi Hematologi dan Onkologi Medik Bagian Penyakit Dalam Fakultas Kedokteran RS Sanglah Denpasar. ejournal.unud.ac.id/.../6 thrombosis\%20dan20usia\%lanjut.pdf diambil 28 Juli 2013.

7. Darmadi. (2008). Infeksi Nosokomial Problematika dan Pengendaliannya. Jakarta: Salemba.

8. Rocca, JC dan Otto, SE. (1998). Terapi Intravena, Alih Bahasa Aniek Maryuni, Penerbit Buku Kedokteran EGC, Jakarta.

9. Hadaway, L.C. (2001). You Role in Preventing Complications of Peripheral I.V Therapy. Springhouse Corporation.

10. Sudijono, A. (2010). Pengantar Statistik Pendidikan. Jakarta: Rajawali Pers.

11. Potter, P.A \& Perry, A.G. (2005). Buku Ajar Fundamental Keperawatan: Konsep, Proses, dan Praktik. EGC, Jakarta. 